\title{
Synthesis and antibacterial activity against ralstonia solanacearum for novel hydrazone derivatives containing a pyridine moiety
}

\author{
Jian $\mathrm{Wu}^{1,2+}$, Shenghong Kang ${ }^{1,2+}$, Baoan Song ${ }^{1,2^{*}}$, Deyu $\mathrm{Hu}^{1,2}$, Ming He $\mathrm{He}^{1,2}$, Linhong Jin ${ }^{1,2}$ and Song Yang ${ }^{1,2^{*}}$
}

\begin{abstract}
Background: Ralstonia solanacearum, one of the most important bacterial diseases on plants, is a devastating, soilborne plant pathogen with a global distribution and an unusually wide host range. In order to discover new bioactive molecules and pesticides acting on tobacco bacterial wilt, we sought to combine the active structure of hydrazone and pyridine together to design and synthesize a series of novel hydrazone derivatives containing a pyridine moiety.

Results: A series of hydrazone derivatives containing a pyridine moiety were synthesized. Their structures were characterized by ${ }^{1} \mathrm{H}-\mathrm{NMR},{ }^{13}$ C-NMR, IR, and elemental analysis. The preliminary biological activity tests showed that compound $3 \mathrm{e}$ and $3 \mathrm{~g}$ exhibited more than $80 \%$ activity against Ralstonia solanacearum at $500 \mathrm{mg} / \mathrm{L}$, especially compound $3 \mathrm{~g}$ displayed relatively good activity to reach $57.0 \%$ at $200 \mathrm{mg} / \mathrm{L}$.

Conclusion: A practical synthetic route to hydrazone derivatives containing a pyridine moiety by the reaction of intermediates 2 with different aldehydes in ethanol at room temperature using 2-chloronicotinic acid and 2-amino5-chloro-3-methylbenzoic acid as start materials is presented. This study suggests that the hydrazone derivatives containing a substituted pyridine ring could inhibit the growth of Ralstonia solanacearum.
\end{abstract}

\section{Background}

Ralstonia solanacearum ( $R$. solanacearum), one of the most important bacterial diseases on plants, is a devastating, soil-borne plant pathogen with a global distribution and an unusually wide host range, which belongs to the $\beta$-proteobacteria and is considered as a "species complex". It causes a wilt disease with deadly effects in many important crops, such as in potato, tomato and eggplant firstly described by Smith in 1896 and subsequently in tobacco in 1908 [1-3]. Once the plants infected with bacterial wilt, the main symptoms of plants were rapid death, but stems and leaves remained green. Tobacco bacterial wilt, caused by $R$. solanacearum, is one of the main plant diseases in tobacco production and occurred in the most common and serious form. The high

\footnotetext{
* Correspondence: basong@gzu.edu.cn; fcc.syang@gzu.edu.cn † Contributed equally

${ }^{1}$ State Key Laboratory Breeding Base of Green Pesticide and Agricultural Bioengineering, Key Laboratory of Green Pesticide and Agricultural Bioengineering, Ministry of Education, Guizhou University, Guiyang, China Full list of author information is available at the end of the article
}

incidence of plant mortality and the lack of effective control methods make $R$. solanacearum become one of the world's most destructive plant pathogens $[4,5]$.

Pyridine is an important class of heterocyclic ring, which have been attracted more and more attention in the pesticides areas due to their broad-activities, such as fungicidal activity [6-8], insecticidal activity $[9,10]$ and herbicidal activity $[11,12]$. In fungicidal activity regard, some pyridine derivatives can prevent Erysiphe graminis, Botrytis cinerea [13], Pyricularia oryzae [14] and Phytophthora infestans [15]. Currently, some pyridine compounds have been developed and commercialized, for example, fluopicolide [16], boscalid [17] and picoxystrobin [18] (Figure 1). In the recent literature, hydrazones demonstrated significant antimicrobial activity [19], antitubercular activity [20] and antitumoral activity [21] in medicinal areas. On the other hand, hydrazones also exhibit good fungicidal activity against Phytophthora infestans [22], Cladosporium сисиmerinum and Colletotrichum orbiculare [23] in the pesticides areas, some of them containing hydrazone structure 
have been commercialized, such as benquinox and ferimzone [24] (Figure 1).

Controlling of plant bacterial diseases has long been a challenging mission in the agricultural sector. The application of traditional pesticides has not proved much effective and at the same time high residue level or negative impact on the environment were caused. Copper formulation, a commercial bactericide can enhance resistance in host tobacco plant. Despite being useful in the treatment of plants affected by tobacco bacterial wilt, the use of copper formulation for field trial is largely limited due to its phytotoxicity, strong alkali and low mobility. Therefore, the search for new antibacterial agent still remains a daunting task in pesticide science [25]. In order to discover new molecules and pesticide acting on tobacco bacterial wilt, we sought to combine the active structure of hydrazone and pyridine together to design and synthesize a class of novel hydrazone derivatives containing a pyridine moiety. Thus, 2-chloronicotinic acid and 2-amino-5-chloro-3methylbenzoic acid were used as start materials, 11 novel analogues of hydrazones containing pyridine were synthesized. All the compounds were unequivocally characterized by IR, NMR and elemental analysis. The biological activities on $R$. solanacearum were tested, the results showed that most of the synthesized compounds exhibited antibacterial activity against $R$. solanacearum to a certain extent, compounds $3 \mathrm{e}$ and $3 \mathrm{~g}$ showed good antibacterial activity at $200 \mathrm{mg} / \mathrm{L}$. especially compounds $3 \mathrm{~g}$ displayed excellent antibacterial activity (57.0\%) at $200 \mathrm{mg} / \mathrm{L}$. To the best of our knowledge, this is the first report on the antibacterial activity of hydrazone derivatives containing a pyridine moiety.

\section{Results and discussion \\ Synthesis}

The synthetic route to the title compounds is demonstrated in Additional file 1. 6- chloro-2-(2-chloropyridin3-yl)-8-methyl-4H-benzo[d] [1,3] oxazin-4-one 1 were prepared by treatment of 2 -chloronicotinic acid with 2-amino-5-chloro-3-methylbenzoic acid using readily available starting materials and a simple procedure as describing in the literature [26]. The further reaction of intermediates 1 with $80 \%$ hydrazine hydrate could proceed readily at room temperature to give intermediates 2 [27]. Subsequent treatment of intermediates 2 with different aldehydes in ethanol at room temperature afforded the desired compounds (3a to $3 \mathrm{k}$ ). The synthetic route in Scheme 1 had several advantages, which included short steps, short reaction times and excellent yields (e.g. the yields for 3b, 3d, 3e and $3 j$ were 93.3\%, 96.6\%, 96.6\% and $93.6 \%$, respectively), especially the mild conditions (room temperature). Additional file shows the structures, yields and elemental analysis data for title compounds in more detail [see Additional file 2].

All the synthesized compounds (3a-3k) were characterized on the basis of their spectroscopic data. The IR absorption bands near $3260-3180 \mathrm{~cm}^{-1}, 3100-2910 \mathrm{~cm}^{-1}$, $1666-1610 \mathrm{~cm}^{-1}, 1600-1575 \mathrm{~cm}^{-1}$ and $1367-1352 \mathrm{~cm}^{-1}$ confirmed the presence of two N-H, Ar-H, amide [28], $\mathrm{C}=\mathrm{N}-[29]$ and $-\mathrm{CH} 3$ functional groups, respectively.<smiles>O=C(NCc1ncc(C(F)(F)F)cc1Cl)c1c(Cl)cccc1Cl</smiles>

fluopicolide<smiles>O=C(Nc1ccccc1-c1ccc(Cl)cc1)c1cccnc1Cl</smiles>

boscalid<smiles>CO/C=C(/C(=O)OC)c1ccccc1COc1cccc(C(F)(F)F)n1</smiles>

picoxystrobin<smiles>O=C(NN=C1C=CC(=NO)C=C1)c1ccccc1</smiles>

benquinox<smiles>C/C(=N/Nc1nc(C)cc(C)n1)c1ccccc1C</smiles>

ferimzone 
In the ${ }^{1} \mathrm{H}$-NMR spectra of the title compounds, the -CONHAr proton appeared as a broad singlet at 12.1710.53; the $-\mathrm{CON} H \mathrm{~N}$ proton appeared as a broad singlet at 10.34-10.17; the $-\mathrm{C}=\mathrm{NH}$ proton mainly appeared as a broad singlet at 8.73-8.20; the pyridine ring of 4 and 6 positions protons were occurred double-double peaks near 8.52-8.51 and 8.01-7.94; the methyl $\left(\mathrm{Ar}-\mathrm{CH}_{3}\right)$ proton signals were observed as a singlet near 2.34-2.30. Meanwhile, we observed the titles compounds possess $E$ and $Z$ configuration in the ${ }^{1} \mathrm{H}-\mathrm{NMR}$ spectra, but the $E$ configuration was mainly forms by the spectra analysis, such as $E$ configuration of -CONHAr proton appeared at 12.11 , but $Z$ proton was occurred at 12.01 in $3 \mathrm{e}$, and the $E / Z$ is approximately equal to 3.60 .

\section{Biological activity and structure-activity relationship}

The antibacterial activity of compounds $3 \mathrm{a}-3 \mathrm{k}$ against $R$. solanacearum was assayed by the reported method [30]. Kocide, one of the proven commercial agents for controlling $R$. solanacearum, was used as the reference of bactericides. The results provided in Table 1 indicate that most of the prepared compounds have weak to good antibacterial activity against $R$. solanacearum at $500 \mathrm{mg} / \mathrm{L}$. Compounds $3 \mathrm{e}$ and $3 \mathrm{~g}$ displayed higher activities than compounds $3 \mathrm{a}-3 \mathrm{~d}, 3 \mathrm{f}$ to $3 \mathrm{~h}-3 \mathrm{k}$ at $500 \mathrm{mg} / \mathrm{L}$. For example, inhibition of $3 \mathrm{e}\left(\mathrm{R}_{2}=3\right.$-trifluoromethylphenyl $)$ and $3 \mathrm{~g}\left(\mathrm{R}_{2}\right.$ $=N, N$-dimethylamino) on tobacco bacterial wilt was $80.9 \%$ and $100.0 \%$ at $500 \mathrm{mg} / \mathrm{L}$, whereas $3 \mathrm{a}\left(\mathrm{R}_{2}=\mathrm{Et}\right), 3 \mathrm{~b}$ $\left(\mathrm{R}_{2}=2\right.$-chlorophenyl $)$ and $3 \mathrm{f}(\mathrm{R}=4$-tert-butylphenyl $)$ was only $5.0 \%, 6.0 \%$ and $39.0 \%$ at the same condition. Primary structure- activity relationships revealed that when the $\mathrm{CONHN}=\mathrm{CHR}_{2}$ was simultaneously substituted by $N$, $N$-dimethylamino (at the $\mathrm{R}_{2}$ group) and 3-trifluoromethylphenyl (at the $\mathrm{R}_{2}$ group), the activity on $R$. solanacearum increased. However, the introduction of $\mathrm{CH}_{2} \mathrm{CH}_{3}$, 2-

Table 1 Antibacterial activity of compounds $3 a$ to $3 \mathbf{k}$, Kocide against $R$. solanacearum

\begin{tabular}{ccc}
\hline & \multicolumn{2}{c}{ inhibition rates (\%) } \\
Compounds & $\mathbf{5 0 0} \mathbf{~} \mathbf{g} / \mathbf{L}$ & $\mathbf{2 0 0} \mathbf{~} \mathbf{g} / \mathbf{L}$ \\
\hline 3a & 5.0 & 0.0 \\
$\mathbf{3 b}$ & 6.0 & 0.0 \\
$\mathbf{3 c}$ & 5.0 & 1.1 \\
$\mathbf{3 d}$ & 18.2 & 15.2 \\
$\mathbf{3 e}$ & 80.9 & 33.3 \\
$\mathbf{3 f}$ & 39.0 & 18.2 \\
$\mathbf{3 g}$ & 100.0 & 57.1 \\
$\mathbf{3 h}$ & 35.0 & 12.4 \\
$\mathbf{3 i}$ & 40.3 & 0.0 \\
$\mathbf{3 j}$ & 25.2 & 1.9 \\
$\mathbf{3 k}$ & 36.1 & 0.0 \\
Kocide $\mathbf{3 0 0 0}$ & 100.0 & 100.0 \\
$\mathbf{C u}(\mathbf{O H}) \mathbf{2}$ & & \\
\hline
\end{tabular}

chlorophenyl, 4-fluorophenyl, 2,6-dichlorophenyl, 4-tertbutylphenyl, 3, 4-dichlorophenyl, 2, 3-dimethoxyphenyl, 2, 4-dimethoxyphenyl and 2, 5-dimethoxy- phenyl groups into $R_{2}$ groups decreased the activity of the compound. Furthermore, the mono- substituent at the different positions on phenyl of the $\mathrm{R}_{2}$ group also affected the bioactivity of the compound. For instance, the compound with trifluromethyl group at 3-position on phenyl ring (3e) displayed good activity, while the compounds with tert-butyl at 4-position on phenyl ring (3f) exhibited moderate activity and the compound with chlorine at 2-position on phenyl ring (3b) and the compound with fluorine at 4-position on phenyl ring (3c) showed no antibacterial activities on $R$. solanacearum. Compared with the same substituents on phenyl, the substituents at the 2, 3-positions, the corresponding molecules always had higher inhibition rates for tobacco bacterial wilt. For example, the inhibition rates of $3 \mathrm{i}\left(\mathrm{R}_{2}=2\right.$, 3-dimethoxyphenyl) and $3 \mathrm{k}$ $\left(R_{2}=2\right.$,4-dimethoxyphenyl) was $40.3 \%, 36.1 \%$ and the inhibition rates of $3 j\left(R_{2}=2,5\right.$-dimethoxyphenyl) on tobacco bacterial wilt was $25.2 \%$.

\section{Experimental \\ Chemistry}

Unless otherwise stated, all the reagents and reactants were purchased from commercial suppliers; melting points were uncorrected and determined on a XT-4 binocular microscope (Beijing Tech Instrument Co., China). The ${ }^{1} \mathrm{H}$-NMR and ${ }^{13} \mathrm{C}$-NMR spectra were recorded on a JEOL ECX 500 NMR spectrometer (JEOL Ltd., Japan) at room temperature operating at $500 \mathrm{MHz}$ for ${ }^{1} \mathrm{H}-\mathrm{NMR}$ and $125 \mathrm{MHz}$ for ${ }^{13} \mathrm{C}$-NMR by using $\mathrm{CDCl}_{3}$ or DMSO as solvents and TMS as an internal standard; infrared spectra were recorded in $\mathrm{KBr}$ on a IR Pristige-21 spectrometer (Shimadzu corporation, Japan); elemental analysis was performed on an Elemental Vario-III CHN analyzer (Elementar, German). The course of the reactions was monitored by TLC; analytical TLC was performed on silica gel GF 254.

Intermediate 1 and 2 were prepared according to the reported methods $[26,27]$ and used without further purifications [Additional file 3].

\section{Antibacterial biological assay}

Antibacterial activities of some title compounds against $R$. solanacearum were evaluated by the turbidimeter test [30], whereas Kocide ${ }^{\circledR} 3000$ was the positive control. The compounds were dissolved in $30 \mu \mathrm{L}$ DMSO and diluted with water containing TWEEN-20 $(0.1 \mathrm{mg} / \mathrm{L})$ to generate a final concentration of $500 \mathrm{mg} / \mathrm{L}$ and $200 \mathrm{mg} / \mathrm{L}$, which were added to the toxic nutrient broth (NB) liquid medium in $5 \mathrm{~mL}$ tubes, respectively. To the above tubes, $40 \mu \mathrm{L}$ NB liquid medium containing $R$. solanacearum pathogen was individually added, then shaken at $30^{\circ} \mathrm{C}$ and 180 r.p.m. for $48 \mathrm{~h}$, the relative inhibition rate of the circle mycelium 
compared to blank assay was calculated via the following equation.

Relative inhibition rate $(\%)=\frac{A_{0}-A_{1}}{A_{0}} \times 100 \%$

$A_{0}$ : Corrected OD values of the control medium of bacilli;

$A_{1}$ : Corrected OD values of the medium of toxic.

\section{Conclusion}

In conclusion, a series of the novel hydrazone derivatives containing a substituted pyridine ring were designed and synthesized. The reaction of intermediates 2 with different aldehydes in ethanol at room temperature used 2-chloronicotinic acid and 2-amino-5-chloro-3-methylbenzoic acid as start materials provides a ready access to a series of the novel hydrazone derivatives containing pyridine moiety. The antibacterial tests indicated that some of the synthesized compounds possessed of moderately high activity against $R$. solanacearum. The title compounds $3 \mathrm{e}$ and $3 \mathrm{~g}$ exhibited favourable activity against tobacco bacterial wilts in vitro compared to the commercial bactericides Kocide 3000. The antibacterial tests showed that when the $R_{2}$ group of $\mathrm{CONHN}=\mathrm{CHR}_{2}$ was 3-trifluoromethylphenyl or $\mathrm{N}, \mathrm{N}$-dimethylamino, the corresponding compounds presented good antibacterial activities. The structure of the target products needs to be optimized to enhance their antibacterial activity. Future structural modification and biological evaluation should be carried out to explore the full potential of this novel class of antibacterial molecules.

\section{Additional material}

\section{Additional file 1: Synthetic route to target compounds 3a-k.}

Synthetic sequence to the novel hydrazone analogues $\mathbf{3}$ containing pyridine ring from 1 and 2.

Additional file 2: Yield and elemental analyses data for title compounds 3a-k. Which contains the a table about structure, yield and elemental analyses data for title compounds $\mathbf{3 a - k}$.

Additional file 3: Experimental details and data of title compounds 3a-k. Which includes the experimental procedure, spectroscopic data of intermediate $\mathbf{1}$, intermediate $\mathbf{2}$, title compounds $\mathbf{3 a - k}$, copies of ${ }^{1} \mathrm{H}$ NMR and ${ }^{13} \mathrm{C}$ NMR.

\section{Acknowledgements}

This work was supported the National Key Program for Basic Research (No. 2010CB 126105), Key Technologies R\&D Program (No.2011BAE06B056) and National Natural Science Foundation of China (No.21162004), the Special Foundation of Governor for Outstanding talents in Guizhou (No.2011-38).

\section{Author details}

${ }^{1}$ State Key Laboratory Breeding Base of Green Pesticide and Agricultural Bioengineering, Key Laboratory of Green Pesticide and Agricultural Bioengineering, Ministry of Education, Guizhou University, Guiyang, China. ${ }^{2}$ Research and Development Center for Fine Chemicals, Guizhou University, Guiyang 550025, China.

\section{Authors' contributions}

The current study is an outcome of constructive discussion with BAS, SY and DYH who offered necessary guidance to JW and SHK to carry out their synthesis and characterization experiments. Both of JW and SHK were also involved in the drafting of the manuscript. $\mathrm{MH}$ performed the Antibacterial tests; LHJ carried out the ${ }^{1} \mathrm{H}$ NMR, ${ }^{13} \mathrm{C}$ NMR spectral analyses and elemental analysis. BAS and SY were involved in revising the manuscript. All authors read and approved the final manuscript.

\section{Competing interests}

The authors declare that they have no competing interests.

Received: 21 January 2012 Accepted: 7 April 2012

Published: 7 April 2012

\section{References}

1. Salanoubat M, Genin S, Artiguenave F, Gouzy J, Mangenot S, Arlat M, Billaultk A, Brottier P, Camus JC, Cattolico L, Chandler M, Choisne N, Claudel-Renard C, Cunnac S, Demange N, Gaspin C, Lavie M, Moisan A, Robert $C$, Saurin W, Schiex T, Siguier $P$, Thébault $P$, Whalen $M$, Wincker $P$, Levy M, Weissenbach J, Boucher CA: Genome sequence of the plant pathogen Ralstonia solanacearum. Nature 2002, 415:497-502.

2. Álvarezi B, Biosca EG, López MM: On the life of Ralstonia solanacearum, a destructive bacterial plant pathogen. In Current research, technology and education topics in applied microbiology and microbial biotechnology. Volume 1. Edited by: Mendez-Vilas A. Spain: Formatex, Bada-joz; 2010:267-279.

3. Li ZF, Wu SL, Bai XF, Liu Y, Lu JF, Liu Y, Xiao BG, Lu XP, Fan LJ: Genome Sequence of the Tobacco Bacterial Wilt Pathogen Ralstonia solanacearum. J Bacteriol 2011, 193:6088-6089.

4. Turner M, Jauneau A, Genin S, Tavella MJ, Vailleau F, Gentzbittel L, Jardinaud MF: Dissection of Bacterial Wilt on Medicago truncatula Revealed Two Type III Secretion System Effectors Acting on Root Infection Process and Disease Development. Plant Physio/ 2009, 150:1713-1722.

5. Mukaihara T, Tamura N: Identification of novel Ralstonia solanacearum type III effector proteins through translocation analysis of $h r$ B-regulated gene products. Microbiology 2009, 155:2235-2244.

6. Minakata S, Hamada T, Komatsu M, Tsubo H, Kikuta H, Ohshiro Y: Synthesis and Biological Activity of $1 \mathrm{H}$-Pyrrolo [2, 3-b] pyridine Derivatives: Correlation between Inhibitory Activity against the Fungus Causing Rice Blast and Ionization Potential. J Agric Food Chem 1997, 45:2345-2348.

7. Bis SJ, Canada EJ, Cooper DH, Galka CS, Kirby N, Ouimette DG, Podhorez DE, Pieczko M, Rezac R, Rieder B, Swayze JK, Hegde VB, Sampson GL: 2-Methoxyimino-2-(pyridinyl oxymethyl)phenyl acetamides with carboxylic acid derivatives on the pyridine ring as fungicides., WO 9833772, 1998[Chem Abstr 1998, 129:161497].

8. Foor SR, Walker MP: Synergistic fungicide compositions containing at least one $\mathrm{N}^{\prime}$ - (2-pyridinyl) methyl-3-pyridinecarboxamide derivative and one or more further fungicides useful for controlling fungal plant diseases., WO 2003079787. 2003[Chem Absr 2003, 140:141086].

9. Wakita T, Kinoshita K, Yasui N, Yamada E, Kawahara N, Kodaka K: Synthesis and Structure-activity Relationships of Dinotefuran Derivatives: Modification in the Nitroguanidine Part. J Pestic Sci 2004, 29:348-355.

10. Shao XS, Xu ZP, Zhao XF, Xu XY, Tao LM, Li Z, Qian XH: Synthesis, Crystal Structure, and Insecticidal Activities of Highly Congested Hexahydroimidazo[1,2-a] pyridine Derivatives: Effect of Conformation on Activities. J Agric Food Chem 2010, 58:2690-2695

11. Hegde SG, Mahoney MD: Synthesis and Herbicidal Activity of 5(Haloalkyl)-Substituted Thiazole [4,5-b] pyridine-3(2H)-acetic Acid Derivatives. J Agric Food Chem 1993, 41:2131-2134.

12. Hanagan MA, Selby TP, Sharpe PL, Sheth RB, Stevenson TM: Herbicidal Amides., WO 2005070889[Chem Abstr 2005, 143:193910].

13. Mansfield DJ, Rieck H, Greul JN, Coqueron PY, Genix P, GrosjeanCournoyer MC, Perez J, Villier A: Preparation of heteroarylcarboxamides as fungicides., EP 1449841, 2004 [Chem Abstr 2004, 141:207064].

14. Watanabe T, Araki N: Pyridylmethyl Derivatives of 2,6-Dichloroisonicotinic Acid, Process for Production of the Same, and Disease Controllers for Agricultural and Horticultural Use., WO 2005068430, 2005[Chem Abstr 2005, 143:172764].

15. Lee SF, Gliedt M: Substituted Isoxazoles as Fungicides., WO, 2006031631 [P]. 2006.. 
16. Mansfield DJ, Cooke T, Thomas PS, Coqueron PY, Vors JP, Briggs GG Lachaise H, Rieck H, Desbordes P, Grosjean-Cournoyer MC: Novel 2Pyridylethylbenzamide Derivative., WO, 2004016088[P]. 2004. [Chem Abstr 2004, 140:176744].

17. Elcken K, Goetz N, Harreus A, Eberhard A, Gisela L, Harald R: Anilide Derivatives and Their Use to Combat Botrytis., EP 0545099, 1993[Chem Abstr 1993, 119:160132].

18. Clough JM, Godfrey CRA, Hutchings MG, Aathony VM: Methyl 3-methoxy2-phenylpropenoate derivatives useful as plant fungicides and plant growth regulators, their fungicidal compositions, and processes and intermediates for their preparation., EP 278595, 1988[Chem Abstr 1988, 109:270725].

19. Küçükgüzei ŞG, Oruç EE, Rollas S, Sahin F, Ozbek A: Synthesis, Characterization and biological activity of novel 4- thiazolidinones, 1,3,4oxadiazoles and some related compounds. Eur J Med Chem 2002, 37:197-206.

20. Rollas S, Gülerman N, Erdeniz H: Synthesis and antimicrobial activity of some new hydrazones of 4-fluorobenzoic acid hydrazide and 3-acetyl2,5-disubstituted-1,3,4-oxadiazo- lines. Farmaco 2002, 57:171-174.

21. Savini L, Chiasserini L, Travagli V, Pellerano C, Novellino E, Cosentino S, Pisano MB: New a-heterocyclichydrazones: evaluation of anticancer, antiHIV and antimicrobial activity. Eur J Med Chem 2004, 39:113-122.

22. Young D, Shaber S, Avila-adame C, Breaux N, Ruiz J, Siddall T, Webster J: Fungicidal compositions including hydrazone derivatives and copper useful for controlling growth of fungi and their preparation., WO 2010083319, 2010[Chem Abstr 2010, 153:204054].

23. Yang XD: Synthesis and biological activity of hydrazone derivatives containing pyrazole. J Chem Res 2008, 9:489-491.

24. Okuno T, Furusawa I, Matsuura K, Shishiyama J: Mode of action of ferimzone, a novel systemic fungicide for rice disease: Biological properties against Pyricularia oryzae in vitro. Phytopathology 1989, 79:827-832.

25. Hayward A: C: Biology and epidemiology of bacterial wilt caused by Pseudomonas solanacearum. Annu Rev Phytopathol 1991, 29:65-87.

26. Lahm GP: Preparation of novel anthranilamides useful for controlling invertebrate pests., WO 2006023783, 2006[Chem Abstr 2010, 144:274265].

27. Wu J, Song BA, Hu DY, Yue M, Yang S: Design, synthesis and insecticidal activities of novel pyrazole amides containing hydrazone substructures. Pest Manag Sci 2011, DOI 10.1002/ps.2329

28. Wu J, Yang S, Song BA, Bhadury PS, Hu DY, Zeng S, Xie HP: Synthesis and insecticidal activities of novel neonicotinoid analogs bearing an amide moiety. J Heterocyclic Chem 2011, 48:901-906.

29. Kandile NG, Mohamed MI, Zaky H, Mohamed HM: Novel pyridazine derivatives: Synthesis and antimicrobial activity evaluation. Eur J Med Chem 2009, 44:1989-1996.

30. Lee JY, Moon SS, Hwang BK: Isolation and in vitro and in vivo activity against Phytophthora capsici and Colletotrichum orbiculare of phenazine-1-carboxylic acid from Pseudomonas aeruginosa strain GCB26. Pest Manag Sci 2003, 59:872-882.

doi:10.1186/1752-153X-6-28

Cite this article as: Wu et al.: Synthesis and antibacterial activity against ralstonia solanacearum for novel hydrazone derivatives containing a pyridine moiety. Chemistry Central Journal 2012 6:28.

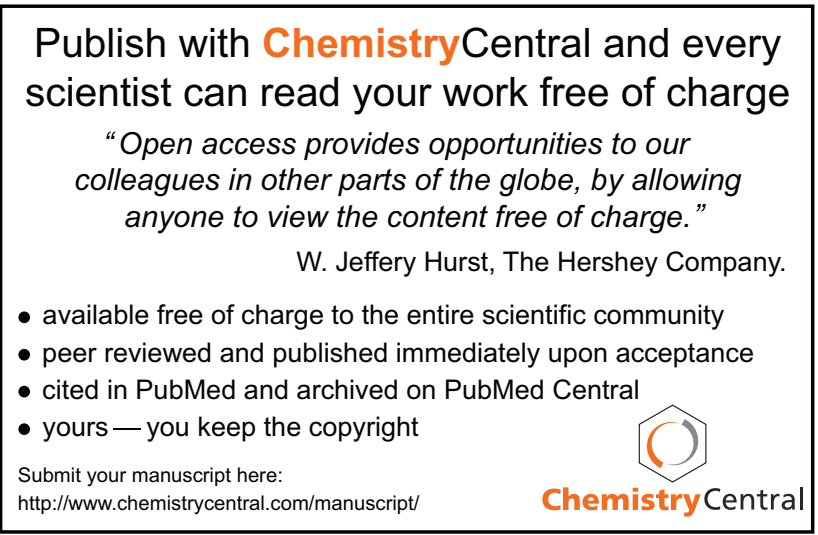

